\title{
A EDUCAÇÃO E RESISTÊNCIA AOS TEMPOS SOMBRIOS: REFLEXÕES A PARTIR DE HANNAH ARENDT
}

\author{
NASCIMENTO, Carlos Eduardo Gomes ${ }^{1}$
}

\begin{abstract}
RESUMO: O trabalho analisa, a partir do pensamento de Hannah Arendt, a concepção de educação e o conceito de mentira organizada. Hannah Arendt, pensadora judia, testemunhou tempos sombrios do regime totalitário na Alemanha em meados do século XX. Com o totalitarismo, a mentira invadiu o espaço público de maneira organizada por meio da propaganda de massa, objetivando destruir o passado, a realidade e a política. Fundamenta-se em textos da autora como "Verdade e Política" (1967) e "A mentira na política" (1971), que chamam atenção pelo fato de que, mesmo findo os regimes totalitários, os riscos da manipulação da realidade e da história ainda espreitam a vida política contemporânea. Para Arendt, no ensaio "Crise na educação" (1958), a educação tem a responsabilidade de introduzir às crianças e aos jovens uma herança cultural e histórica de um mundo comum. Por fim, busca defender que, mesmo diante de todos os riscos, a educação ainda é um contraponto à mentira organizada.
\end{abstract}

PALAVRAS-CHAVE: Mentira organizada, Educação, Hannah Arendt.

\section{EDUCATION AND RESISTANCE TO DARK TIMES: REFLECTIONS FROM HANNAH ARENDT}

\begin{abstract}
The work analyzes, based on Hannah Arendt's thinking, the concept of education and the concept of organized lying. Hannah Arendt, a Jewish thinker, witnessed the dark times of totalitarian rule in Germany in the mid-20th century. With totalitarianism, lies invaded public space in an organized way, through mass propaganda aimed at destroying the past, reality and politics. It is based on texts by the author such as "Verdade e Política" (1967) and "A lie in politics" (1971), which call attention to the fact that, even after totalitarian regimes have ended, the risks of manipulating reality and history still lurk contemporary political life. For Arendt in the essay "Crisis in education" (1958), education has a responsibility to introduce children and young people to a cultural and historical heritage of a common
\end{abstract}

\footnotetext{
${ }^{1}$ Mestre em Educação pela Universidade Federal da Bahia - UFBA

Jangada | nr. 15, jan/jun, 2020 | ISSN 2317-4722 
world. Finally, it seeks to defend that even in the face of all the risks, education is still a counterpoint to the organized lying.

KEYWORDS: Organized lying, education, Hannah Arendt.

\section{UMA PERSPECTIVA ARENDTIANA SOBRE A EDUCAÇÃO EM TEMPOS SOMBRIOS}

A pensadora política Hannah Arendt tomou de empréstimo a expressão "tempos sombrios", do poeta Bertolt Brecht (2012), no poema “Aos que virão depois de nós”. Em seu livro "Homens em tempos sombrios" (2014), a autora revelou uma relação de amizade - entre vivos e mortos, contemporâneos e antepassados - para narrar vidas de homens e mulheres, tais como Rosa Luxemburgo, Walter Benjamin, Bertold Brecht e Gottfried Lessing. As ações daquelas pessoas foram exemplo de resistência contra toda forma de violência, principalmente nos regimes totalitários que surgiram durante a primeira metade do século XX. A voz do poeta refletiu sobre a violência e o sentimento de injustiça no período totalitário:

Eu vivo em tempos sombrios.

Uma linguagem sem malícia é sinal de estupidez,

Uma testa sem rugas é sinal de indiferença.

Aquele que ainda ri é porque ainda não recebeu a terrível notícia.

Que tempos são esses,

Quando falar sobre flores é quase um crime.

Pois significa silenciar sobre tanta injustiça?

Aquele que cruza tranquilamente a rua

Já está então inacessível aos amigos

Que se encontram necessitados?

(BRECHT, 2012, p. 36)

A partir do poema de Brecht, Arendt (2014) também mostrou a violência e o terror da monstruosidade dos regimes totalitários. Um tempo de supressão da liberdade, do aniquilamento da ação política e da conivência com o outro, que resultou na miséria e no ódio. 
O momento histórico vivido por Brecht e Arendt marcou o sentimento de solidão que tomou conta das mentes e dos corações de parte de uma geração, em que qualquer gesto, palavra e ação opostos ao poder seriam brutalmente silenciados. No entanto, mesmo frente ao terror de um tempo sombrio, houve resistência na voz do poeta e na escrita histórica, na busca pela verdade factual contra a mentira organizada e na luta pela preservação de um legado cultural. Arendt escreveu

Que mesmo no tempo mais sombrio temos o direito de esperar alguma iluminação, e que tal iluminação pode bem provir, menos das teorias e conceitos, e mais da luz incerta, bruxuleante e frequentemente fraca que alguns homens e mulheres, nas suas vidas e obras, farão brilhar em quase todas as circunstâncias e irradiarão pelo tempo que lhes foi dado na Terra. (ARENDT, 2014, p. 7)

Atualmente, a expressão "tempos sombrios" vem sendo utilizada popularmente em artigos de jornais, na tv, em lives e podcasts para representar a ideia sobre o conturbado momento político mundial no início do século XXI. Arendt, Brecht e outros denominaram a vida no regime totalitário como um "tempo sombrio", um momento histórico específico, que não deve ser aproximado ao contemporâneo sem uma maior reflexão e cuidado. No entanto, pelo planeta, alguns mandatários do Poder Executivo eleitos democraticamente agem de modo paradoxal, acobertados pela legitimidade de parte da população, e perpetram ataques aos próprios princípios democráticos, à liberdade de expressão e aos direitos humanos em defesa de um regime autoritário.

A ascensão desses projetos políticos autoritários ditatoriais põe em risco a democracia, trazendo à lembrança o pesadelo do totalitarismo. Arendt (1985) observou

\footnotetext{
A distinção decisiva entre o domínio totalitário, baseado no terror, e as tiranias e ditaduras, impostas pela violência, é que o primeiro volta-se não apenas contra os seus inimigos mas também contra os amigos e correligionários, pois teme todo o poder, até mesmo o poder dos amigos. O clímax do terror é alcançado quando o Estado policial começa a devorar os seus próprios filhos, quando o carrasco de ontem torna-se a vítima de hoje. É este o momento quando o poder desaparece inteiramente. (ARENDT, 1985, p. 30)
}

Causa estranhamento que, em países democráticos como o Brasil, uma parcela da população e alguns ocupantes de cargos do poder estatal utilizam elementos do terror para Jangada | nr. 15, jan/jun, 2020 | ISSN 2317-4722 
defender um regime de violência; representantes eleitos elogiam a tortura e a pena de morte no Congresso Nacional; um Secretário de Cultura faz um pastiche nefasto de um discurso da propaganda totalitária; a Educação e a Ciência tornam-se alvos da mentira por um novo instrumento - fake news -, que invade o espaço público; e a vida é relativizada pela falácia do poder econômico sobre a pandemia de um novo vírus que fez o planeta parar.

Perante a iminência do colapso do sistema de saúde, ocupantes do poder do Estado têm mostrado ineficiência e, muitas vezes, desprezo pela vida de seus eleitores. Seria o prenúncio do "clímax do terror", em que o Estado violento "começa a devorar os seus próprios filhos"? De modo monstruoso, a escolha entre quem vive e quem morre nos hospitais por falta de aparelhos médicos tem sido apelidada de "A Escolha de Sofia", em referência ao romance de William Styron, adaptado para o cinema, cuja história relata o trauma de uma mulher judia em um campo de extermínio, que, acuada pelo terror totalitário, faz uma escolha de vida e de morte.

Os tempos sombrios objetivaram destruir a capacidade e a diversidade histórica humana. A mentira organizada em massa foi seu instrumento a fim de colocar um final na história, apagar o passado e qualquer expectativa quanto ao futuro. Tratava-se da tentativa de aniquilação do passado não mais contado, não mais ouvido pelas futuras gerações, nem convertido em histórias.

No ensaio “A crise na educação" (2011), a autora chamou atenção e convocou todos os seus contemporâneos para a responsabilidade na preservação de uma herança cultural e no cuidado com a educação dos novos. A crise na educação converge com algumas de suas principais reflexões filosóficas, tais como: o esfacelamento do mundo comum pela perda da tradição, a ameaça de esquecimento do passado e a imprevisibilidade da convivência humana na política. Tais proposições fazem parte da crise do período moderno e pertencem aos assuntos humanos da geração presente, colocando em aberto o pensamento e a ação livre na política.

Para Hannah Arendt (2011), a educação é o acolhimento de novos seres humanos, as crianças e os jovens, na herança de um mundo comum. Nesse ponto, os adultos devem fazer uma escolha: se acolhem ou se rejeitam as crianças e os jovens, que são como recém-chegados em um território estranho, permeado de cultura, histórias e saberes. Assim, semelhante a um estrangeiro, cada um deles tem consigo uma potencialidade única para agir quando adultos no espaço público, como portadores de uma novidade singular, com capacidade de contribuir com os outros e de transformar o mundo. 
Esse acolhimento da singularidade presente em cada criança na educação possibilita que ela se sinta herdeira de atos e das experiências criadas no passado, proporcionando um sentimento de pertença ao mundo, a fim de que as crianças e jovens possam sentir-se em casa. Com essa perspectiva, a educação passa pelo reconhecimento de que todos os seres humanos possuem o direito de pertencer ao "espaço-entre" (ARENDT, 2017, p. ???), um mundo plural e diverso.

Segundo a pensadora, "a essência da educação é a natalidade, o fato de que seres humanos nascem no mundo" (ARENDT, 2011, p. 223). Essa relação entre a natalidade e a educação dá-se por conta do mundo possuir um passado e uma história, uma herança comum que pode ser capaz de "iluminar" o tempo presente por meio da experiência e memória das antigas gerações. A natalidade é "o fato de todos nós virmos ao mundo ao nascermos e de ser o mundo constantemente renovado mediante o nascimento" (ARENDT, 2011, p. 247). Com a natalidade, os seres humanos não apenas nascem no sentido biológico, mas pertencem a uma herança cultural.

A partir do legado deixado pela obra de Hannah Arendt, analisa-se os perigos da mentira organizada na política e na educação brasileira. A autora observou a propaganda e a ideologia de massa que surgiram com os regimes totalitários no século XX, mas que ainda hoje constituem perigo ao espaço democrático contemporâneo.

Será que tempos sombrios se avizinham sobre a democracia e a educação brasileira? A mentira, a verdade e a política e sua relação com a educação: esses serão os elementos analisados no decorrer do texto, porque a sociedade deve manter-se mais alerta e vigilante quando a produção da mentira apresenta-se como verdade dos fatos e quando educadores e suas ideias são perseguidos pelo Estado.

\section{VERDADE FACTUAL E A EDUCAÇÃO}

Hannah Arendt não se dizia filósofa, mas uma pensadora política. Talvez por conta disso tenha problematizado a verdade na política, ou seja, na ação livre humana sobre os negócios públicos, diferentemente de muitos pensadores na história da filosofia. A verdade, dessa forma, pode ser lida, interpretada e narrada a partir dos fatos que constituem um solo historicamente tecido por mãos humanas. Segundo Correia (2014),

Com efeito, Arendt realmente insiste na distinção entre verdade e opinião, tendo em vista principalmente objetar uma tradição política ainda vigorosa, 
de matriz platônica, que tendia a julgar que é possível encontrar um critério último, extrapolítico, capaz de dirimir de uma vez por todas o conflito das opiniões dos cidadãos na praça pública. A oposição à qual ela se refere não é, portanto, entre teoria e prática, mas entre a verdade filosófica de matriz metafísica e o caráter incontornavelmente perspectivo de toda opinião que circula no âmbito político. (CORREIA, 2014, p. 167)

Arendt mostrou-se interessada em debater a verdade e a política examinando os problemas do exercício da ação livre. Uma das distinções realizadas pela autora é que a verdade e a opinião não são idênticas. Nesse sentido, a autora atribuiu outra percepção sobre a relação entre verdade e opinião. A opinião está presente no espaço público e na diversidade de posições em virtude da pluralidade e do domínio dos negócios humanos. A opinião, objeto de disputa na política, expressa a liberdade que os seres humanos possuem no âmbito das decisões, mas que encontra limites na verdade dos fatos.

Assim, a opinião não deve ser confundida com a verdade, que é autoevidente e coercitiva, pois está além do acordo, da disputa ou do consentimento (ARENDT, 2011, p. 297). A verdade, na visão de Arendt (2011), pode ser compreendida de duas formas: a verdade racional (concernente às investigações filosóficas, matemáticas e científicas) e a verdade factual (resultado de eventos e fatos que dizem respeito ao âmbito político na tessitura do domínio da ação).

As sentenças "os três ângulos de um triângulo são iguais aos dois ângulos de um retângulo" e "a terra move-se em torno do sol”, citadas por Arendt (2011), são exemplos da verdade racional e autoevidente, uma matemática e outra natural. Observou Arendt (apud ALMEIDA, 2010, p. 861): "O que a ciência e a busca de conhecimento procuram é a verdade irrefutável, ou seja, proposições que os seres humanos não estão livres para refutar - são coercitivas". Embora a verdade filosófica também seja racional, ela não possui a mesma força coercitiva que a matemática e a científica, pois não pode ser provada da mesma forma: por exemplo, a proposição "é melhor sofrer o mal do que praticar o mal” (ARENDT, 2011, p. 297).

A verdade dos fatos diz respeito ao domínio político que preserva a história composta pela ação e palavras de gerações passadas no mundo comum. Para Arendt,

O mundo comum é aquilo que adentramos ao nascer e que deixamos para trás quando morremos. Transcende a duração de nossa vida tanto no passado quanto no futuro, preexistia à nossa chegada e sobreviverá à nossa breve 
permanência nele. É isso o que temos em comum não só com aqueles que vivem conosco, mas também com aqueles que aqui estiveram antes e com aqueles que virão depois de nós. Mas esse mundo comum só pode sobreviver ao vir e ir das gerações na medida em que aparece em público (ARENDT, 2016, p. 68).

A verdade factual não é objeto de disputa política, de acordo com Arendt (2011): "conceitualmente, podemos chamar de verdade aquilo que não podemos modificar; metaforicamente, ela é o solo sobre o qual nos colocamos de pé e o céu que se estende acima de nós". A verdade dos fatos compõe o solo do mundo comum e se impõe como limite contra toda forma de manipulação deliberada da história.

Não se pode, por exemplo, negar a existência de fatos criminosos como o tráfico de pessoas negras africanas que foram escravizadas no Brasil até fins do século XIX, assim também não se pode contestar o genocídio de judeus pelo Holocausto durante a Segunda Grande Guerra. A verdade delimita a ação política livre, mas movimenta-se dentro de limites. Há condições que não permitem a invenção, pois os fatos estão postos (ALMEIDA, 2010, p. 862). Assim, não se pode negligenciar uma verdade factual, de maneira que não se pode inventar que não houve o crime de genocídio no Holocausto ou no tráfico de pessoas negras: são crimes que atentaram contra a humanidade. Essa é uma verdade factual que está no testemunho de sofrimento e de dor em diversas gerações.

A verdade factual também está gravada na memória e na palavra dos poetas e de escritores, na criação artística e nos registros historiográficos. Esse é um testamento de um legado culturalmente criado por gerações que nos precederam. A verdade factual revela-se, também, como um testemunho, isto é, uma prova da veracidade e da existência da ação no mundo comum.

As narrativas de poetas, historiadores e artistas chegam ao presente como uma mensagem da existência não só da matéria factual, mas também possibilita que a geração atual possa compreender as ações do passado. Segundo Arendt (2011), não se pode admitir o direito de tocar na própria matéria factual. Para exemplificar, a pensadora cita um diálogo entre dois políticos, que se questionavam acerca da culpa pela eclosão da Primeira Guerra Mundial. O primeiro político pergunta: “O que em sua opinião pensarão os historiadores futuros desse tema espinhoso e controverso?”, e o outro responde: “Isso não sei. Mas tenho certeza de que eles não dirão que a Bélgica invadiu a Alemanha". Trata-se de uma matéria factual em que as tropas da 




Alemanha, na noite de 4 de agosto de 1914, cruzaram a fronteira da Bélgica.

Nesse sentido, quando na escola uma professora conta às crianças a história de uma obra de arte, como Guernica (1937), o quadro do pintor espanhol Pablo Picasso, que representa um fato histórico e diz respeito à matéria factual, ao bombardeio aéreo por caças nazistas em apoio ao fascismo espanhol contra a cidade de Guernica; também quando essa mesma professora faz a leitura de um poema de Luiz Gama sobre a história de luta das pessoas negras por direitos e contra a política escravagista do estado brasileiro no século XIX; ou quando ela exibe um filme que registra que houve um estado de exceção no período entre os anos de 1964 e 1985 no Brasil, a Ditadura Militar, com perseguição e mortes de diversos cidadãos, a professora narra a história, a verdade factual, que possibilita ao estudante encontrar um lugar no mundo.

Essas narrativas históricas, científicas e literárias proporcionam uma reflexão sobre o passado, sobre as ações no presente e sobre as possíveis consequências no futuro. Ao conhecer a obra de arte, a história e a ciência, o jovem pode inspirar-se na possibilidade de também ser um artista, um cientista ou uma professora.

No entanto, a ascensão dos regimes totalitaristas e o seu tempo sombrio foi capaz de produzir uma ruptura com a tradição e com as diversas narrativas transmitidas de geração a geração. Acontecimento que representou um perigo à verdade factual — frágil ante a manipulação e o falseamento deliberado promovidos pelo nazifascismo.

A tradição, a capacidade humana de selecionar, nomear, transmitir e preservar o legado histórico, científico e cultural do mundo comum, tornou-se fugidia aos olhos daquela geração que viveu os horrores do regime totalitário (ARENDT, 2011, p. 31), uma geração que não se reconhecia nas experiências do passado, não encontrando mais laços, origens ou qualquer espécie de vínculo. A tradição teve seus fios cortados face ao passado, pois não mais se poderia "recorrer a experiências autênticas e incontestes comum a todos" (ARENDT, 2011, p. 127). Com a perda da tradição, uma concepção importante à educação, tornou-se difícil para os educadores estabelecerem uma mediação entre o passado e o presente, quebrando a continuidade da história.

No entanto, mesmo com os fios da tradição cortados, tal acontecimento, para Arendt (2011), não deveria acarretar "necessariamente, a perda da capacidade humana de constituir, preservar e cuidar de um mundo que nos pode sobreviver e permanecer um lugar adequado à vida para os que vêm após". Nessa perspectiva arendtiana, na educação e na escola, um espaço 
plural, ocorre a introdução da criança em uma herança cultural mais ampla e diversa, narrada por professoras e professores, representantes do mundo (ARENDT, 2011, p. 239), que possuem a autoridade cuidar e proteger o passado.

Não há sentido em falar do mundo comum, um legado e uma herança cultural, transmitido às futuras gerações sem a conservação do testemunho daqueles que nos precederam, seja na escrita de historiador ou nos versos do poeta. Conservar significa transmitir as histórias aos mais jovens, aproximando-os dos acontecimentos e das experiências do passado. Para Arendt,

Exatamente em benefício daquilo que é novo e revolucionário em cada criança é que a educação precisa ser conservadora; ela deve preservar essa novidade e introduzi-la como algo novo em um mundo velho, que, por mais revolucionário que possa ser em suas ações, é sempre, do ponto de vista da geração seguinte, obsoleto e rente à destruição. (ARENDT, 2011, p. 243)

A conservação na educação, através da perspectiva arendtiana, traz a possibilidade de que as narrativas e as histórias sejam não apenas transmitidas aos estudantes, mas que, nas mãos deles, se possa criar condições para algo novo e revolucionário. Uma das características da ação humana é a de sempre iniciar algo novo, segundo Arendt (2016). Conforme Almeida (2008): “A educação não é uma técnica que procura prever todas as variáveis possíveis de ação das gerações futuras, para daí guiar as crianças pela variável que julgar adequada. Ao contrário, a educação deve voltar-se para o velho, que é o 'chão' para o novo, mas que não o determina”.

Para iniciar-se o novo, demanda-se ser introduzido em uma diversidade de histórias e experiências. Isto é, na educação e, especialmente, na escola, as crianças tomam contato com as diferenças entre sujeitos e culturas. Na perspectiva arendtiana, a educação não é o lugar para o exercício da política, das decisões sobre os negócios humanos, muito menos as escolas são laboratórios de ensaio sobre como os estudantes devem comportar-se como futuros cidadãos. A escola não é o espaço do político por excelência, mas possui uma dimensão pré-política (ARENDT, 2011, p. 240). Isto não significa dizer que a escola seja uma preparação stricto sensu para o espaço público. A escola exerce sua função na formação humana, na medida em que as crianças e os jovens podem lidar com o conhecimento, o passado e o pensamento.

O conhecimento expõe a verdade dos fatos não apenas sobre o passado, mas também na compreensão do presente. E tudo que diz respeito à verdade factual pode sofrer um insidioso assédio do poder. Assim, quando o poder político impõe um único pensamento e elimina a Jangada | nr. 15, jan/jun, 2020 | ISSN 2317-4722 
pluralidade pedagógica, a falsidade deliberada ultrapassa o campo da política para adentrar outros espaços compartilhados como a educação. A educação fragiliza-se sem a compreensão da realidade e do passado, fazendo crescer o perigo de perder a diversidade cultural e histórica. Acerca do campo público Hanna Arendt observou

As possibilidades de que a verdade factual sobreviva ao assédio do poder são de fato por demais escassas; aquela está sempre sob o perigo de ser ardilosamente eliminada do mundo, não por um período apenas, mas, potencialmente, para sempre. Fatos e eventos são entidades infinitamente mais frágeis que axiomas, descobertas e teorias — ainda que os mais desvairadamente especulativos — produzidos pelo cérebro humano; ocorrem no campo das ocupações dos homens, em sempiterna mudança em cujo fluxo não há nada mais permanente do que a permanência, reconhecidamente relativa, da estrutura da mente humana. Uma vez perdidos, nenhum esforço racional os trará jamais de volta. (ARENDT, 2011, p. 287)

A verdade dos fatos não está segura nas mãos do poder (ARENDT, 2011, p. 319), quando a mentira se insere na política. Conforme Duarte (2000): “é preciso impedir que a mentira e a manipulação possam converter-se nos elementos centrais do discurso político, de sorte que a luz do espaço público deixe de revelar novas perspectivas do mundo e passe a escondê-las e destruí-las". A educação é ameaçada pela mentira não apenas no que diz respeito à verdade dos fatos, mas também em toda a dimensão temporal de testemunhos, sobre as ações e as palavras, narradas e transmitidas às próximas gerações.

\section{A MENTIRA ORGANIZADA}

Bendito inferno!

Pra cometer seus mais negros pecados,

Os demônios começam celestiais,

Como eu agora: enquanto o tolo honesto

Pede a Desdêmona que o ajude e salve,

E ela por ele há de implorar ao Mouro,

Eu derramo em seu ouvido o veneno

Que é por luxuria que ela o quer de volta;

E, quanto mais busca ajudá-lo,

Mais o descredita junto ao Mouro; 
Transformo assim sua virtude em piche,

E com sua bondade eu teço a rede

Que há de enredar os três

(SHAKESPEARE).

Esse trecho do monólogo de Iago, personagem de "Otelo, o Mouro de Veneza", uma tragédia de William Shakespeare, mostra as artimanhas da organização meticulosa da mentira. O personagem Iago mostra-se um mentiroso capaz de tudo para destruir Otelo, o governador mouro de Chipre e general do exército veneziano. A mentira criada por Iago não tem escrúpulos: agindo com a mais absoluta frieza, ele enreda mais que um adultério: a sua mentira forja o amor de Desdemona, esposa de Otelo, por um outro homem. No mundo da mentira, o que importa para Iago é a satisfação de seu ego e, talvez por conta disso, ele se torna o primeiro a acreditar na "verdade" de suas mentiras para depois, meticulosamente, convencer a todos.

A mentira é um ato em que alguém modifica ou dissimula deliberadamente aquilo que ele reconhece como verdadeiro, induzindo o outro a acreditar ser verdadeiro o que sabidamente é falso. A mentira pressupõe uma intencionalidade em dizer o falso. Aquele que decide mentir não o faz por descuido, falta de atenção ou por ignorância: age de maneira proposital, para ocultar ou apagar a verdade. Na peça de Shakespeare, Iago, o mentiroso, está em um ambiente privado, onde tece uma rede de mentiras contadas ao pé do ouvido de Otelo. Ao longo da história humana, a mentira não aparece apenas em situações particulares, ela adentra outros domínios como a política.

Arendt (2011) lembra que a sinceridade nunca foi uma virtude dos políticos, por ser uma ferramenta, principalmente, utilizada pelo demagogo, pois a mentira, quando adentra e domina a esfera pública, torna-se uma arma eficiente contra a verdade. Nessa condição, a mentira na política pode ser usada de maneira organizada com o objetivo de desestabilizar a verdade dos fatos, a história e a vida dos indivíduos. Para Duarte (2000),

O problema da mentira na política torna-se grave e urgente, quando ela deixa de ser tópica e passa a abranger todo um contexto em que os fatos contingentes tornam-se significativos, bem como quando ela passa a redefinir os contornos do presente e do passado por meio da reescritura da história. Nessas circunstâncias, a mentira [...] é a arte de destruir toda evidência que a contradiga, destruindo, assim, o próprio tecido do espaço público ao apagar completamente as fronteiras entre fato e ficção. (DUARTE, 2000, p.185) 
Uma herança maldita totalitária, a mentira organizada alastrou-se como verdadeiro transe para o desaparecimento do próprio espaço político e das referências históricas. Escreveu Arendt (2016): “os verdadeiros transes do nosso tempo somente venham a assumir a sua feição autêntica - embora não necessariamente a mais cruel - quando o totalitarismo pertencer ao passado". O que Arendt parece chamar atenção é que a terra pode viver um novo transe, quando a realidade começa a ser distorcida e a democracia e a liberdade sofrem com os resquícios totalitários das técnicas de propaganda de massa da mentira organizada. Para Pereira (2017),

A instrumentalização moderna da mentira na política atenta inclusive contra a realidade; ela implica uma forma de tornar "verdade" uma mentira, uma falsidade. O risco está no apagamento da linha demarcatória entre ficção e realidade. É por essa razão que a instrumentalização da mentira, como mentira organizada, mira a possibilidade de apagar fatos testemunhados e conhecidos. A intenção de ser uma mentira geral, de massa, toca justamente no aparato que é o garantidor da realidade, o aparecer relacional dos fatos. (PEREIRA, 2017, p. 93)

Ainda assim, no espaço político democrático, a mentira pode surgir e sustentar a simulação da realidade, desempenhando a vil forma estratégica de organizar-se para convencer a opinião pública. Arendt (2015), no artigo “A mentira na política”, analisou os documentos do Pentágono, departamento de defesa dos Estados Unidos da América, que validaram a guerra do Vietnã ${ }^{2}$. Sua análise sobre os documentos não apenas demonstrou que a realidade foi simplesmente ignorada e manipulada, mas também ocorreu o menosprezo aos fatos históricos, políticos e geográficos. Para a pensadora: "A veracidade nunca esteve entre as virtudes políticas, e mentiras sempre foram encaradas como instrumentos justificáveis nestes assuntos" (ARENDT, 2015, p. 15). É nesse teatro de mentiras que surge a figura do mentiroso, que, deliberadamente, distorce a realidade para locupletar-se com sua própria torpeza. Ainda segundo Arendt (2015),

\footnotetext{
${ }^{2} \mathrm{O}$ domínio do mentiroso sobre os meios de comunicação digitais de massa vem possibilitando que a rede de mentiras opere um controle ainda mais eficaz na vida cotidiana das pessoas nos Estados democráticos. Os casos como, por exemplo, do WikiLeaks, que revelou, em 2010, os detalhes de documentos secretos dos Estados Unidos para as guerras no Afeganistão e Iraque; o caso Edward Snowden, em 2013, que levou a público o programa de vigilância maciça, organizado pelas agências norte-americanas, em escala mundial, tais acontecimentos evidenciaram a vigilância e o controle em massa sobre a vida das pessoas por meio do uso da tecnologia digital.
} 
A mentira não entra em conflito com a razão, pois as coisas poderiam perfeitamente ser como o mentiroso diz que são. Mentiras são frequentemente muito mais plausíveis, mais clamantes à razão do que a realidade, uma vez que o mentiroso tem a grande vantagem de saber de antemão o que a plateia deseja ou espera ouvir. (ARENDT, 2015, p. 16)

O mentiroso ou os mentirosos contumazes buscam abolir e entorpecer a capacidade da opinião pública de pensar criticamente a realidade. O mentiroso, como Iago, de modo ordenado, prepara a sua narrativa falsa com um enredo cheio de pantomimas e discursos falaciosos, explorando a razão e a emoção para o clamor de sua plateia. Acerca da figura do mentiroso, ela foi descrita por Arendt (2011):

Ele é um ator por natureza; ele diz o que não é por desejar que as coisas sejam diferentes daquilo que são - isto é, ele quer transformar o mundo. Ele tira partido da inegável afinidade da nossa capacidade de ação, de transformar a realidade, com a misteriosa faculdade que nos capacita a dizer o sol brilha quando chove a cântaros. (ARENDT, 2011, p. 309)

A credibilidade de suas falsidades deliberadas, quando aplaudida por uma plateia sequiosa pela mentira, faz do próprio mentiroso e da plateia vítimas do engodo, pois "quanto mais bem-sucedido seja o mentiroso, mais provável é que acabe por acreditar em suas próprias mentiras" (ARENDT, 2015, p.38). Nesse contexto em que um elemento do totalitarismo ganha lugar na política, a opinião — que faz parte do dissenso e da construção perene da democracia -, assim como a verdade dos fatos, sai de cena para criar-se um mundo de mentiras.

O mentiroso é "um homem de ação" (ARENDT, 2011, p. 309) que conhece previamente o seu público, disseminando deliberadamente a falsidade com o objetivo de adequar a realidade aos seus prazeres, ao seu modo pessoal de ver o mundo, menosprezando outras perspectivas. O mentiroso, aproveitando-se do poder que exerce no espaço político para agir e "transformar" o mundo; substituindo a realidade pelo delírio ficcional; usando estratégias e instrumentos para a mentira organizada, desperta o medo, manipula os desejos e comportamentos, estimulando o preconceito entre as pessoas.

A verdade factual e histórica, ameaçada pelo oportunismo político do mentiroso, precisa continuamente ser defendida com o máximo de questionamentos e debates públicos. Conforme Arendt (2011): “[...] quando uma comunidade adere ao mentir organizado por 
princípio, e não apenas em relação a particularidades, a veracidade como tal, sem o apoio das forças distorcivas do poderio e do interesse, se torna fator político de primeira ordem”. Dessa maneira, quando mentirosos operam a falsidade deliberada na política por princípio, aqueles sujeitos que se contrapõem à mentira pesquisando, analisando e apresentando a ciência e a verdade dos fatos históricos também começam a agir,

Onde todos mentem acerca de tudo que é importante aquele que conta a verdade começou a agir; quer o saiba ou não, ele se comprometeu também com os negócios políticos, pois, na improvável eventualidade de que sobreviva, terá dado o primeiro passo para a transformação do mundo. (ARENDT, 2011, p. 311)

Daí o medo que o mentiroso sente dos cientistas, historiadores, professores, jornalistas e poetas, que lidam com o trabalho árduo de apresentar ao público a verdade factual e racional. Pois no mundo em que paira tempos sombrios, obliterado por mentiras, esses atores resistem politicamente pelo simples ato de manifestar a história, o conhecimento, os fatos e a ciência.

\section{EDUCAÇÃO E A RESISTÊNCIA AOS TEMPOS SOMBRIOS}

Atualmente, diante de uma realidade de violência, a mentira encontrou um terreno fértil para organizar-se na política e na educação. E não seria estranho questionar se o Brasil não estaria flertando com os tempos sombrios?

Relata-se que na tarde de 05 de abril de 2019, na escola estadual Frederico de Barros Brotero, na cidade de Guarulhos, no estado de São Paulo, jovens estudantes do turno noturno foram surpreendidos com a chegada de policiais, fortemente armados, chamados pela direção da escola para reprimir um protesto por melhorias na própria instituição. Durante a confusão, um policial apontou uma arma de grosso calibre para os alunos e, se já não bastasse a violência da ação, com toda brutalidade, colocou a cano da arma no peito de Eduarda Sória, uma jovem estudante de 17 anos e, com toda força, empurrou a garota. Mesmo com forte solavanco, o fuzil não disparou, evitando que a tragédia fosse ainda pior (AzMina, 2019).

A violência ao redor da escola em diversas comunidades no Brasil tem aumentando na história recente. Em março de 2017, a estudante Maria Eduarda Alves da Conceição, de 13 anos, durante uma aula de educação física, morreu vítima de um tiro após tiroteio entre policiais e traficantes. Em 2018, o adolescente Marcos Vinicius da Silva, de 14 anos, e a pequena 
Ketellen Gomes, de 5 anos, em 2019, também foram vítimas de balas perdidas. É um período histórico de aguda violência que adentra o espaço escolar, destrói a vida e aterroriza crianças e adolescentes. Causa estranheza a falta de mobilização da sociedade brasileira diante de tantos uniformes escolares manchados de sangue. A banalização da violência no espaço para a aprendizagem e para o cuidado revela que se vive em tempos da mais vil covardia contra crianças e adolescentes, em especial aqueles pobres e negros.

Concomitantemente, outras formas de violência também acometem a educação brasileira. Professoras e professores vêm sofrendo a desvalorização profissional não só com a desídia de entes federativos no cumprimento da determinação da Lei n ${ }^{\circ} 11.738 / 2008$, que prevê o pagamento do piso nacional do magistério, mas também com Projetos de Lei $^{3}$ que atacam princípios fundamentais da educação nacional como a liberdade de aprender, de ensinar, de pesquisar e divulgar a cultura, de pensamento; a arte e o saber; o pluralismo de ideias e de concepções pedagógicas; o respeito à liberdade e apreço à tolerância; consideração à diversidade étnico-racial entre outros.

Projetos de lei, originados do obscurantismo, que apregoam que nas escolas brasileiras há "o abuso da liberdade de ensinar" dos professores, em um contexto estranho à democracia, com a supressão da diversidade e restrição da apresentação de um mundo plural aos jovens. Entre as justificativas do Projeto de Lei (PL) nº 193/2016, que tramita no Senado Federal,

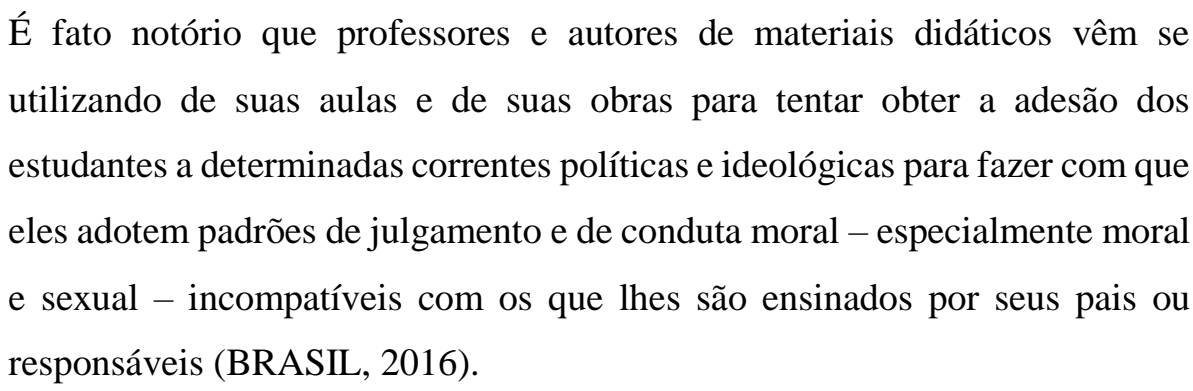

Trata-se da tentativa de criminalizar a prática docente, algo semelhante ao ocorrido durante regimes totalitários. Esse tema vem ganhando apoio de parte da população a partir de novos instrumentos da mentira organizada na política - as fake news (notícias fraudulentas), que são disseminadas pelas redes sociais e aplicativos de comunicação. Semelhantes às propagandas de massa dos regimes totalitários, as fake news espalham mentiras sobre

\footnotetext{
${ }^{3}$ Na Câmara Federal há três projetos tramitando: o Projeto de Lei (PL) 7180/2014, do deputado Erivelton Santana (PSC/BA); o PL 867/2015, de Izalci Lucas (PSDB-DF) e o PL 1411/2015, de Rogério Marinho (PSDB/RN). E, no Senado Federal, o PLS 193/2016, de autoria do Senador Magno Malta (PR-ES).
}

Jangada | nr. 15, jan/jun, 2020 | ISSN 2317-4722 133 | P á g in a 
professores, responsabilizando-os pelo ensino de supostas doutrinações política e sexual, por termos como "ideologia de gênero" e distribuição de "kit gay" nas escolas.

Ceifar a importância e a responsabilidade dos professores é uma das primeiras medidas do flerte de um regime autoritário com os elementos do totalitarismo, como a censura de ideias, a aniquilação da oposição política e o apagamento da história e do conhecimento. Essas são formas de infligir a violência às crianças e aos professores na escola, marcando uma aproximação aos tempos sombrios.

Tempos sombrios legitimados por projetos de lei vexatórios que objetivam tornar a escola um lugar de censura, de discriminação e de preconceito. Essa proposta de amordaçar docentes e a livre expressão dos alunos incide num processo de exclusão. A escola tornou-se alvo da vigilância e da punição, conforme previsão do PL nº 867/2015:

As escolas afixarão nas salas de aula, nas salas dos professores e em locais onde possam ser lidos por estudantes e professores, cartazes com o conteúdo previsto no Anexo desta Lei, com, no mínimo, 70 centímetros de altura por 50 centímetros de largura, e fonte com tamanho compatível com as dimensões adotadas. As secretarias de educação contarão com um canal de comunicação destinado ao recebimento de reclamações relacionadas ao descumprimento desta Lei, assegurado o anonimato (BRASIL, 2015).

A descrição detalhada sobre conteúdo, tamanho e local onde deve ser afixado o cartaz mostra que os elementos da barbárie totalitária espreitam a democracia e a educação brasileira. Com tais projetos de lei, nenhuma professora, professor ou aluno estarão seguros para ensinar, questionar, aprender e criar na escola. A educação é invadida pelo mais vil confronto político por meio da organização da mentira. E resistir à mentira organizada, que busca controlar a realidade e tudo o que diz respeito ao passado, é uma das tarefas da educação. Por isso, educadores, professores, alunos e a sociedade não podem abrir mão de lidar com a verdade dos fatos e a verdade racional, na medida em que o testemunho e a herança cultural de gerações passadas estão presentes em obras de arte, na poesia, na história das descobertas científicas.

Falar a verdade factual e apresentar o mundo comum aos novos constitui um liame fundamental na construção da vida política e do cuidado com a história e a cultura deixada por aqueles que se foram. A importância do ato de lembrar para assegurar a verdade dos fatos e a realidade pelos testemunhos foi lembrada por Arendt (2015): 
[A verdade factual] está sempre correndo o risco de ser perfurada por uma única mentira ou despedaçada pela mentira organizada de grupos, países ou classes, ou negada e distorcida, muitas vezes cuidadosamente acobertada por calhamaços de mentiras, ou simplesmente autorizada a cair no esquecimento. Fatos necessitam de testemunhos para serem lembrados, e de testemunhas confiáveis para serem oficializados, de modo a encontrar um lugar seguro para habitar o domínio dos interesses humanos. (ARENDT, 2015, p. 16)

Hanna Arendt apostou na natalidade como essência da educação, na singular novidade que cada criança tem no mundo, na verdade dos fatos, na história, na memória e na imaginação, importantes elementos para a educação como resistência às tentativas de os tempos sombrios organizarem a mentira. Assim, o testemunho humano para a liberdade na poesia de Brecht e de Luiz Gama, no pensamento de Arendt e no quadro "Guernica", de Pablo Picasso, são a expressão da durabilidade do mundo comum e impulsionam a todos na educação para resistir à ameaça da mentira.

\section{CONCLUSÃO}

Após sobreviver aos tempos sombrios, Hannah Arendt tentou compreender como foi possível seres humanos cometerem tantas atrocidades contra outros seres humanos a partir de um projeto de poder baseado na violência e no ódio. A pensadora política, uma testemunha daqueles fatos históricos, narrou os perigos da perda do sentimento de pertencimento ao mundo comum pelas ações do totalitarismo.

A mentira, a propaganda e a ideologia em massa constituíram-se como elementos dos regimes totalitários. As técnicas de propaganda baseadas na falsidade deliberada e na fidelidade cega não só a um líder, mas a uma ideia única, configuraram a eclosão do poder totalitário através da mentira organizada. Essa fabricação de informações fraudulentas em massa caracterizou uma tentativa de apagar o passado e destruir o espaço público.

A narrativa de Arendt constitui-se, enquanto um legado transmitido às próximas gerações, como um alerta para o perigo da mentira organizada. A produção de informações fraudulentas sobre a realidade e sobre o passado ainda espreita os dias atuais mesmo após o fim dos regimes totalitários, principalmente no momento histórico de afirmação das instituições democráticas em vários países. O espaço democrático preceitua a pluralidade de ideias, o respeito à singularidade de cada pessoa e estimula a preservação da diversidade, fundamentos 
que precisam continuamente ser ensinados às novas gerações.

Com a tentativa de desarticular a educação pela mentira, professores, professoras, jovens estudantes e parte da sociedade lutam para garantir o direito de conhecer e de pertencer ao abrigo do mundo comum. Assim como aquele que enfrenta os perigos para dizer a verdade dos fatos no espaço público em tempos sombrios da mentira organizada, a educação também é um exercício da coragem não só em apresentar a verdade dos fatos, mas em transmitir aos mais novos um legado plural.

Para que algo não seja invariavelmente quebrado e esquecido sem que sequer seja nomeado pelo efeito traiçoeiro da mentira organizada, a educação pode vir a ser um baluarte de resistência. Portanto, os atores da educação, em tempos sombrios, têm a responsabilidade de agir e de resistir contra o cenário perfidamente produzido por qualquer instrumento insidioso da mentira. Como lembram Gilberto Gil e Caetano Veloso na letra da música "Divino, maravilhoso", interpretada por Gal Costa (1969), em momentos decisivos "é preciso estar atento e forte", mesmo diante da fragilidade da vida e da educação, pois "não temos tempo de temer a morte", a fim de preservar o conhecimento, a história, a ciência e as artes para as futuras gerações.

\section{REFERÊNCIAS BIBLIOGRÁFICAS}

AGUIAR, Odílio Alves; MARIANO, Rosiane. A poesia de Hannah Arendt. In: Artefilosofia. Ouro Preto, n.15, dezembro 2013.

ALMEIDA, Vanessa Sievers de. A distinção entre conhecer e pensar em Hannah Arendt e sua relevância para a educação. In: Educ. Pesqui. [online]. 2010, v. 36, n. 3, p. 853-865.

ALMEIDA, Vanessa Sievers de. Educação e liberdade em Hannah Arendt. In: Educ. Pesqui. [online]. 2008, v. 34, n. 3, p. 465-479.

ARENDT, H. A condição humana. $13^{\mathrm{a}}$ ed. Trad. Roberto Raposo. Rio de Janeiro: Forense Universitária, 2017.

. Da violência. Brasília: Editora da Universidade de Brasília, 1985.

. Entre o passado e o futuro. $6^{\mathrm{a}} \mathrm{ed}$. Trad. Mauro W. Barbosa. São Paulo: Perspectiva, 2011 
. A Dignidade na política. Rio de Janeiro: Relume-Dumará, 2006.

. Homens em tempos sombrios. Trad. Denise Bottmann. São Paulo: Companhia das Letras, 2014.

Origens do totalitarismo. Trad. Roberto Rapouso. São Paulo: Companhia das Letras, 2016.

Crises da República. $2^{\text {a }}$ ed. São Paulo: Editora Perspectiva, 2015.

AZMINA. Quero um futuro, mas com escola assim está difícil. Disponível em: $<$ https://azmina.com.br/reportagens/quero-um-futuro-mas-com-escola-assim-esta-dificil-dizestudante-ameacada-com-fuzil-por-policial/?fbclid=IwAR2_rax6RT11MMLpvSwv9X8J11uxkxv2BpLN8H7LbUKnpM9pCF9rnYURik>. Acesso em: 26 de abril de 2019.

BRECHT, B. Poemas (1913 - 1956). Seleção e tradução de Paulo Cesar de Sousa. São Paulo: Editora 34, 2012.

BRASIL. Base Nacional Comum Curricular (BNCC). Brasília: MEC. 2017. Disponível em: < http://basenacionalcomum.mec.gov.br/images/BNCC_20dez_site.pdf > Acesso 20 maio 2018. BRASIL. Lei de Diretrizes e Bases da Educação Nacional. Lei n ${ }^{0}$ 9.394, 20 de dezembro de 1996.

BRASIL. SENADO FEDERAL. Projeto de Lei $n^{\circ}$ 867, de 2015. Disponível em: < https://www25.senado.leg.br/web/atividade/materias/-/materia/125666 >. Acesso em 16 de setembro de 2019.

BRASIL. CÂMARA FEDERAL. Projeto de Lei do Senado n 193, de 2016. Disponível em: < https://www.camara.gov.br/proposicoesWeb/fichadetramitacao?idProposicao=1050668 >. Acesso em 16 de setembro de 2019.

CARVALHO, José Sérgio Fonseca de. EDUCAÇÃO, UMA HERANÇA SEM TESTAMENTO: diálogos com o pensamento de Hannah Arendt. São Paulo: Perspectiva, 2017

CORREIA, Adriano. Hannah Arendt e a Modernidade - Política economia e disputa por uma fronteira. Rio de Janeiro: Forense Universitária, 2014.

DUARTE, A. O pensamento à sombra da ruptura: política e filosofia em Hannah Arendt. São Paulo: Paz e Terra, 2000.

FLOYD, Pink. The wall. Londres: Harvest Records, 1979. 2 discos (81 min).

ORWELL, George. 1984. São Paulo: Companhia das Letras, 2009. 
G1, 2019. 'Mãe, não chora, não, mãe', disse menina de 5 anos após ser baleada na Zona Oeste do Rio. https://g1.globo.com/rj/rio-de-janeiro/noticia/2019/11/13/pai-de-crianca-morta-no-riodiz-que-atirador-fez-sinal-como-se-pedisse-desculpa-por-ter-baleado-a-menina.ghtml . Acesso em 13 de nov. de 2019.

Gal Costa. Gal Costa. CBD Philips, 1969.

PEREIRA, Geraldo Adriano Emery. O problema da verdade na obra de Hannah Arendt. Tese de Doutorado (UFMG), 2017.

PICASSO, P. Picasso: dessins et gouaches 1899-1972. Paris: Galerie Louise Leiris, 1981. 46p. il. p.b. color. Catálogo: P586 1981.

SHAKESPEARE, William. Otelo: o mouro de Veneza. Edição: Ridendo Castigat Mores. Disponível em: < http://www.ebooksbrasil.org/adobeebook/otelo.pdf > Acesso em: 02 setembro 2019.

STANFORD UNIVERSITY. Stanford researchers find students have trouble judging the credibility of information online. https://ed.stanford.edu/news/stanford-researchers-findstudents-have-trouble-judging-credibility-information-online Acesso em 09 de jul. 2019. 